InOdia $\quad \begin{aligned} & \text { InMedia } \\ & \text { The French Journal of Media Studies }\end{aligned}$

7.1. $\mid 2018$

Visualizing Consumer Culture

\title{
"They All Trust Mickey Mouse": Showcasing American Capitalism in Disney Theme Parks
}

\section{Thibaut Clément}

\section{(2) OpenEdition \\ 12 Journals}

\section{Electronic version}

URL: http://journals.openedition.org/inmedia/1021

DOI: 10.4000/inmedia.1021

ISSN: 2259-4728

\section{Publisher}

Center for Research on the English-Speaking World (CREW)

\section{Electronic reference}

Thibaut Clément, " "They All Trust Mickey Mouse": Showcasing American Capitalism in Disney Theme Parks », InMedia [Online], 7.1. | 2018, Online since 20 December 2018, connection on 08 September 2020. URL : http://journals.openedition.org/inmedia/1021 ; DOI : https://doi.org/10.4000/inmedia. 1021

This text was automatically generated on 8 September 2020 .

(C) InMedia 


\title{
"They All Trust Mickey Mouse": Showcasing American Capitalism in Disney Theme Parks
}

\author{
Thibaut Clément
}

1 In the mid-1950s, and only a few months apart, the United States witnessed two seemingly unrelated developments that were to exert a strong influence on the future of the country's retail industry. Disneyland, the first theme park ever built, opened on July 17, 1955, in Anaheim, 20 miles south of Los Angeles. The Southdale Shopping Center - the world's first fully enclosed shopping mall - followed soon after on October 8, 1956, at Medina, in Minnesota's Twin Cities area. While serving apparently distinct purposes, both addressed new conditions in post-World War II America: the slow decay of downtowns, the need for family-friendly meeting places for middle-class suburbanites, not to mention the rise of shopping and consumption as a leisure activity in its own right. For Disneyland is-also-a mall: like a world unto itself, the park provided visitors with a complete array of stores and restaurants, all matched to the surrounding area's or attractions' theme.

2 And yet, for all its appearances as a self-enclosed and self-sufficient business, Disneyland (just as later Disney parks) does not operate in realms of fantasy entirely divorced from the outside world. ${ }^{1}$ Indeed, this paper's primary intent is to evaluate how Disney's showmanship has helped the company enlist the technical or financial support of major outside corporations, whose products and messages are carefully woven into the parks' narratives of progress and prosperity. Shopping and exposure to corporate messages have become so integral to the visitor's experience and to the Disney parks' business model that some sociologists such as Alan Bryman now speak of "Disneyization," meaning "a mode of delivery [and] staging of goods and services [...] to increase the appeal of goods and services that might otherwise appear mundane or uninteresting." ${ }^{2}$

3 But, while the parks' promotion of capitalism and, more particularly, corporations has been widely noted, the specific terms of their participation in the parks' overall 
business model or their implications regarding the political economy of the media have seldom been discussed. ${ }^{3}$ Instead, critics have primarily focused on how the presence of corporations affects the parks' ideological subtext, especially with regards to the themes of technological progress and consumption. This article will consequently examine how Disneyland's unique business ecosystem has allowed the Walt Disney corporation to pitch itself as the corporations' ideal partner for their communication efforts with the general public, evidencing transformation in the United States' postWorld War II economy as well as mass media's role in the process.

4 The analysis will rest in part on essential, yet often overlooked (at least in academic discussions) primary sources by Disney park designers, managers, and collaborators, including fan-oriented books published by the Walt Disney corporation, as well as more confidential internal documents collected by fans or held in university archives. ${ }^{4}$ While the occasionally self-serving dimension of documents intended for external audiences may of course invite caution, such first-hand accounts provide much needed new insight into the creation and management of the parks' commercial environment. Those documents will be complemented by equally untapped secondary sources, such as works of fan scholarship, including fan-published autobiographies of park managers, "unofficial encyclopedias," or chronicles of the parks' creation stories. ${ }^{5}$

5 The article's primary focus will be on American parks, from Disneyland's inception to the late 1990s/early 2000s, when corporate sponsorships in Disney theme parks began to lose steam. It will break into three parts. It will first examine how Disneyland's environment celebrates consumption and-much in keeping with the studio's earlier merchandising efforts-ties Disney images and narratives with the purchase of goods and services (I). The paper will then turn to Disneyland's appeals to outside partners, allowing the park to serve as a showcase for the products and messages of large U.S. corporations (II). In its third and last part, this study will show that, starting with the conceptualization of ЕРCOT Center, the participation of major conglomerates has become central to the design, funding, and contents of Disney parks and attractions (III). In its concluding remarks, the paper will eventually analyze the Disney corporation's relation with American industry through the lens of the Political Economy of Communication.

\section{Staging consumerism in Disney theme parks}

6 An early example of media convergence, the studio's transition into the theme parks business meant an expansion of Disney's activities not only across multiple media platforms but into such fields of industry such as retail or service. In this regard, Disney's efforts to extend the media-sphere to other areas of business built on its pioneering foray into merchandising, when the studio began to license its crowdpleasing characters to outside companies looking to improve their brand image and boost their sales.

\section{Tying media and consumption: the case of Disney merchandise}

7 Though not the first animation studio to capitalize on the sale of its characters for use by others, Disney was the first to most systematically employ this model for its development, using almost any opportunity to cash in on outside companies' 
willingness to associate their brand with Disney's rising star. ${ }^{6}$ Less than a year after his first public appearance (in the 1929 short Steamboat Willie), Mickey Mouse's likeness already graced school writing tablets (the first Disney merchandise recorded) or embroidered handkerchiefs. Throughout the 1930s, the studio's mascot seemed to drive sales almost as fast as it captured the nation's hearts, saving Depression-hit companies from bankruptcy on at least two occasions. Selling more than 235,000 units within four months, a $\$ 1$ Mickey-and-Minnie windup handcar reportedly helped bring the Lionel toy train company back to solvency after months of sluggish sales. Ingersoll Waterbury likewise found a surprise hit with its Mickey Mouse watch, selling 11,000 units at New York's Macy's on the day of its release and allowing the company to expand its staff from 300 to 3,000 in a matter of weeks. ' Such examples of success helped keep Disney's licensing office busy throughout the entire decade, securing agreements with seventyfive manufacturers in the United States, forty-five in England, twenty in Canada (not to mention six in France, Spain, and Portugal, each). ${ }^{8}$

Not restricted to sole licensing partnerships, Disney's merchandising efforts largely hinged on the cooperation of outside companies eager to exploit the popularity of Disney's characters, as exemplified by the spectacular development in the 1930s of the Mickey Mouse Clubs. Developed in close cooperation with toy manufacturers, theater operators, and department store owners (where membership cards were procured), the club's role was to tie together the consumption of Disney films and Disney toys, boosting audiences and sales for both at once. Meetings were held in movie-theaters and took on the form of Saturday matinee programs, mixing talent contests and other "character-building" activities with a healthy dose of Disney shorts. Designed as a mutually beneficial arrangement, the scheme not only allowed theater operators to fill their venues when virtually no adult would patronize them; by forcing recruits to regular trips to the department stores' toy section, it also encouraged the year-long consumption of toys, retailers and toy manufacturers hoped. ${ }^{9}$

With over 1,500 chapters and somewhere between 150 and 200,000 members by the end of the decade, the clubs proved an overnight sensation-at a time when parents were desperate to provide cheap forms of leisure for their entertainment-starved kids. One of the club's effects was to turn Disney shorts into advertisements for consumer goods branded with Mickey Mouse or any other of the studio's characters. Disney managers conversely reasoned that the pervasiveness of Disney products in households kept kids "Mickey Mouse minded" and worked as a "daily advertisement" for cartoons, earning the studio the loyalty of young audiences. ${ }^{10}$

\section{Shoptainment in Disney theme parks}

10 It is no surprise, then, that ever since its opening in 1955, Disneyland has presented itself not only as yet another offering in Disney's ever-expanding media galaxy but also as an additional vehicle for the sale of products more or less closely related with the Disney brand. To some extent, consumption has been elevated to one of the park's underlying themes and motifs, with shopping itself promoted to the status of entertainment. Somewhat reflected by the parks' near-equal shops-to-attractions ratio (there currently are 50 shops and restaurants to 49 attractions at Disneyland), this conflation of shopping with entertainment results in part from staging techniques that immerse shoppers into canonical story worlds to increase the appeal of products on 
sale. ${ }^{11}$ The presentation and sale of real products and services in Disneyland's imaginary locales provides a good case of what Alan Bryman calls "hybrid consumption" (otherwise known as "shoptainment"), that is the "transformation of shopping into play"-when, thanks to the park designers' showmanship, "consumption becomes part of the immersion into fantasy." ${ }^{12}$ As a result, shopping comes to be framed as part of a broader media experience, yet again tying consumption with images and narratives primarily associated with the Disney brand. By the park designers' own admission, the purchase of souvenirs is critical to the visitor's symbolical participation in the park's fictional worlds-offering a tangible payoff to an otherwise immaterial and momentary experience:

The shops afford guests an added dimension of experience in a time and a world different from the everyday; they turn shopping into entertainment. [...] of course the shops and the restaurants increase the park's profitability; they also enhance each ride or attraction's value by offering themed connections to something realreal food, real souvenirs, something guests can keep. ${ }^{13}$

11 Disneyland's blending of real consumption and imaginary participation is central to what some critics have identified as the parks' "commodification of emotions," suggesting that far more than mere material goods, what visitors pay for in the parks is some form of symbolical and emotional gratification. ${ }^{14}$ As a 1962 training manual puts rather bluntly: "The guest pays us to make him happy"-a somewhat crude rendition of Disneyland's original mission statement, "We create happiness." 15

12 A prominent case in point of how Disney's showmanship serves to create an atmosphere conducive to consumption, Main Street USA (the park's obligatory point of entry) houses no major attractions but instead is almost exclusively devoted to shopping. Recreating the Main Street of a mid-sized city in the Gay Nineties, the land's underlying theme is, quite unabashedly, that of joyous consumerism-the celebration of an age of newfound prosperity and material abundance for all, as a result of mass production and mass consumption. ${ }^{16}$ Disney's is a business-friendly take on the Gilded Age-one expunged of all traces of social strife and discontent (in what was otherwise a turbulent era) and where business is presented as inherently conducive to technological and economic progress. ${ }^{17}$ This vision of a post-scarcity America is supported by the street's vibrant visual environment, as exemplified by the shop's oversized windows (lower than usual, so that children can peer inside), their constantly replenished shelves, as well as their extremely ornate façades, whose lavish decorative details and elaborate millworks bear witness to advances in mass production techniques..$^{18}$ As one official Disney guidebook has it, Main Street is a tribute to "Walt's heartfelt patriotism," "a place where people are friendly, hard work is rewarded, and everybody shares a dream for a better life." ${ }^{19}$ It is the very spirit of American capitalism and its virtues that the land's Emporium at Orlando's Magic Kingdom aims to demonstrate. Meant to convey the success story of its imaginary owner, the store's flourishing business is made especially apparent by its luxurious expansion. The new wing's modern Edwardian style provides a striking contrast with the Victorian decoration of the store's original location, suggesting growth over time as well as conveying something of the owner's Protestant work ethics, whereby profits have been systematically reinvested in the means of production. ${ }^{20}$ 


\section{Corporate partnerships in Disney theme parks}

13 Parks serve as a platform not just for the sale and promotion of Disney-related products, but also of goods and brands from outside companies. Not only does the inclusion of everyday products and brands help increase the realism of their fantasy environments, it also allows parks to operate as promotional vehicles for large corporations while significantly increasing their profit margin in the process.

\section{Sponsors and lessees}

One such form of corporate partnership in Disneyland is the sale of commercial leases to outside companies. Born out of technical and economic necessity, these partnerships allowed lessees to provide technical help and expertise in sectors of business (especially the service industry) initially unfamiliar to the Disney corporation. Just as importantly, those deals allowed the company to not only offload the costs of staffing and operating a number of shops and restaurants, but also collect rents, providing a much-needed source of additional revenue at a time when few investors backed Disney's project yet. ${ }^{21}$ At the park's opening in 1955, Bank of America was thus left in charge of running and staffing Main Street U.S.A.'s bank..$^{22}$ Somewhat more surprisingly, five agribusiness giants were made responsible for managing restaurants serving the products they had become most famous for. Those were Frito Lay, Aunt Jemima's, Chicken of the Sea, Swift \& Co, and Maxwell House. ${ }^{23}$ These early partnerships most likely served as opportunities for skills transfers from the outside in, when the Disney corporation grew confident that not only shops represented a steady source of extra revenue but also that it could run them itself. ${ }^{24} \mathrm{~A}$ great many leases were therefore not renewed upon their expiration, and so did Maxwell's Coffee House close within two years-only to be taken over internally. In addition to leases, other commercial partnerships were struck for the sale of distribution rights to a few corporations essentially paying for exclusive access to Disneyland's closed market-much in contradiction of the park's apparent glorification of economic competition. Those deals restricted not only the items that visitors could buy (with Kodak the sole purveyor of film), but also what products restaurants could use (such as Oscar Mayer hot dogs or Borden milk). ${ }^{25}$

Not just restricted to leases or distribution rights, commercial deals with outside companies also involved the sale of advertisement real estate, with parks serving as showcases for the products and know-how of American titans of industry. By "sponsoring" an attraction, companies would not only attach their names to it but also display their products in thematically appropriate environments, exposing them to millions of captive visitors. Initially limited to the attractions' queue areas, corporate exhibitions grew into attractions in their own rights-as exemplified by the wildly popular Monsanto Home of the Future. Designed and built by Monsanto, the attraction was meant to demonstrate advances in the plastics industry, as applied to construction and home appliances. Naturally enough, Tomorrowland's attractions offered countless opportunities for sponsorship by technological corporations like General Electric, Bell Systems, or Monsanto-which, from 1955 to 1972, took on alone the sponsorship of four attractions in total (see Table $n^{\circ} 1$ : List of Disneyland's 33 participants, 1967). ${ }^{26}$ 
Table $\mathrm{n}^{\circ} 1$ : List of Disneyland's 33 participants, 1967

\begin{tabular}{|c|c|}
\hline Atchison, Topeka and Santa Fe & Santa Fe \& Disneyland Railroad, 1955-1974 \\
\hline Atlantic-Richfield & $\begin{array}{l}\text { Fantasyland Autopia, 1959-1999; Tomorrowland Autopia, } \\
1959-2000\end{array}$ \\
\hline $\begin{array}{l}\text { Aunt Jemima's (originally a subsidiary } \\
\text { of Quaker Oats Company) }\end{array}$ & $\begin{array}{l}\text { Aunt Jemima's Pancake House, 1955-1962, later Aunt } \\
\text { Jemima's Kitchen, 1962-1970 }\end{array}$ \\
\hline Bank of America & Bank of Main Street, 1955-1992 \\
\hline Bell Telephone & Bell telephone Systems Phone Exhibits, 1960-1984 \\
\hline Carnation & $\begin{array}{l}\text { Carnation Ice Cream Parlor, 1955-1997, later renamed } \\
\text { Carnation Café, 1997-ongoing }\end{array}$ \\
\hline C \& H Sugar & C\&H Sugar Corner, Market House, 1965-1970 \\
\hline $\begin{array}{l}\text { Chicken of the Sea, Van Camp } \\
\text { Company }\end{array}$ & $\begin{array}{l}\text { Pirate Ship Restaurant, 1955-1982 and Skull Rock } \\
\text { Restaurant, 1961-1982 }\end{array}$ \\
\hline Coca-Cola & $\begin{array}{l}\text { Refreshment corner, 1955-present; Spirit of Refreshment, } \\
\text { 1998-present; Tomorrowland Terrace, 1967-present }\end{array}$ \\
\hline Douglas Aircraft & Moonliner, 1962-1967 \\
\hline $\begin{array}{l}\text { Frito Lay (merged with Pepsi-Co in } \\
\text { 1965) }\end{array}$ & Casa de Fritos, 1955-2001 \\
\hline General Electric & Carousel of Progress, 1967-1973 \\
\hline Global Van Lines & Main Street Lockers and Storage, 1963-1979 \\
\hline Goodyear Tire and Rubber Co. & PeopleMover, 1967-1995 \\
\hline Hallmark & Hallmark Card Shop, 1960-1985 \\
\hline Hills Bros. Coffee Inc. & Hills Bros. Coffee House and Coffee Garden, 1958-1976 \\
\hline $\begin{array}{l}\text { INA-Insurance Company of North } \\
\text { America }\end{array}$ & Carefree Corner, 1956-1974 \\
\hline $\begin{array}{l}\text { Ken-L Ration (originally a subsidiary } \\
\text { of Quaker Oats Company) }\end{array}$ & Ken-L Land Pet Motel, 1958-1967 \\
\hline Kodak & Kodak Camera Center, 1955-1977; 1977-1994. \\
\hline Lincoln Savings and Loan & Great Moments with Mr. Lincoln, 1965-1973 \\
\hline Monsanto Co. & $\begin{array}{l}\text { Hall of Chemistry, 1955-1966; House of the Future, } \\
\text { 1957-1967; Adventure Thru Inner Space, 1967-1972 }\end{array}$ \\
\hline
\end{tabular}




\begin{tabular}{|l|l|}
\hline Pendleton & Pendleton Woolen Mills Dry Goods Store, 1955-1990 \\
\hline Pepsi-Cola & $\begin{array}{l}\text { Golden Horseshoe Revue, 1955-1982 } \\
\text { Country Bear Jamboree, 1971-1981 }\end{array}$ \\
\hline Spice Islands & Le Gourmet, 1966-1998 \\
\hline Sunkist Growers, Inc. & $\begin{array}{l}\text { River Belle Terrace; Sunkist Citrus House, 1960-1989; } \\
\text { Sunkist, I Presume, 1962-1992 }\end{array}$ \\
\hline Sunsweet Growers Inc. & Market House, 1965-1970 \\
\hline Swift \& Co. & $\begin{array}{l}\text { Red Wagon Inn, 1955-1965; Chicken Plantation, 1955-1962; } \\
\text { Market House, 1955-1965 }\end{array}$ \\
\hline Timex & Watches and Clocks, 1955-1971 \\
\hline United Air Lines & The Enchanted Tiki Room, 1964-1973 \\
\hline The Upjohn Co. & The Upjohn Pharmacy, 1955-1970 \\
\hline The Welch's Grape Juice Company Inc. & Welch's Grape Juice Stand, 1956-1981 \\
\hline Western Printing and Litho Co. & Story Book Shop, 1955-1995 \\
\hline Wurlitzer & Wurlitzer Music Hall, 1955-1968 \\
\hline
\end{tabular}

\section{Compiled from: Strodder, The Disneyland Encyclopedia.}

Even corporate lessees operating restaurants and businesses at Disneyland came to regard their involvement primarily as publicity stunts, as the exorbitant leases soon demanded by the Disney corporation eventually made all hopes of breaking even irrelevant. Lessees, Disney managers argued, were to regard their participation from a pure publicity standpoint and content themselves with basking in the park's alleged "halo effect"-namely, the privilege of associating the participants' operations with one of the United States' most beloved institutions. ${ }^{27}$ In truth, Disney managers were only taking advantage of motivations that had been apparent all along. Food conglomerates such as Aunt Jemima's or Frito Lay had, of course, no particular interest in running a restaurant of their own, if not to reinforce their brand's image and connection with the country's culinary traditions by making their homes at Main Street U.S.A. or Frontierland.

\section{Disneyland's twin functions: medium and shopping center}

17 As both a retail outlet and a medium, Disneyland is also at least in part the product of similar conditions which gave rise to the shopping center and television, as well as served similar objectives. Both developments supported new marketing techniques for the promotion of consumption. Madison Avenue was quick to make television its medium of choice, allowing the advertising industry to develop its scope and methods dramatically over the decade. ${ }^{28}$ The development of malls and large national retail 
chains likewise made the United States' retail environment increasingly compatible with product standardization and mass consumption.

In this regard, Disneyland's twin function helps address the nature of its relations with outside companies, which are at once tenants in Disneyland's commercial environment and advertisers on its "show." The Walt Disney Company thus adopted the standard television practices of corporate sponsorship of entertainment or product placement within show content. ${ }^{29}$ Disneyland likewise replicated not only the form and function of 1950s malls but also their mode of operation and tenant selection. The park presented the same inward-looking, pedestrian, and semi-public environment, surrounded with ample parking space and in direct proximity with major thoroughfares (in Disneyland's case, the Santa Ana Freeway, completed 1956). Crucially, it also borrowed shopping centers' practice of "merchandising,"-the fine-tuned assortment of shops and lessees, reflecting identical efforts among mall developers and operators for the creation of a planned market environment. ${ }^{30}$

Four criteria seem to have guided the choice of participants, and preference was given to companies (1) whose wares, services, or brand image were a good fit with the land's theme; and (2) whose expertise was needed for running the park or supplying content. Participants were also expected to (3) be prosperous enough not to mind the high costs of running an operation at Disneyland; and (4) not compete with other corporations already present in the park. This final condition suffered occasional exceptions. Lincoln Savings and Loans, for example, took up the sponsorship of Great Moments with Mr. Lincoln, even though Bank of America already was already running the Bank of Main Street. Both Coca-Cola and Pepsi-Cola were likewise initially sold at Disneyland, with Pepsi the sponsor of both Frontierland's Golden Horseshoe Revue and Bear Country's Country Bear Jamboree until 1981.

Unsurprisingly, major corporations represented in Disneyland (many the product of mega-mergers and near-monopolistic operations) were from sectors of industry identified with post-World War II economic growth, whose contribution to and promotion of consumerism was essential in shaping new ways of life. This was especially true of the automotive industry, represented by car tires manufacturer Goodyear, oil company Richfield, or carmaker AMC, briefly Circarama's sponsor (1955-1960). A leading contributor to the United States' economic growth, the car industry at one point employed up to one-sixth of the country's total workforce and soon established itself as a decisive promoter of the consumerist lifestyle, through its practice of planned obsolescence, its reliance on the advertising industry, or even its indirect contribution to sprawl and resulting malls. Also, prominently represented in the parks were the agribusiness sector (which in the 1950s witnessed a boom in processed, and especially frozen, foods), the plastics industry (with polymers like DuPont's polyethylene the new material of choice for mass-produced consumer goods), or the service sectors. The presence of both INA-Insurance Company of North America and Bank of America notably spoke to America's new suburban, consumerist condition. INA emerged from World War II one of the United States' largest insurance companies thanks in part to its tremendously successful all-inclusive homeowners policy, while Bank of America and its rivals thrived by providing credit (home loans or consumer credit) on levels unseen since the 1920s. ${ }^{31}$ 


\section{Disney, the middleman between corporations and the public: the case of EPCOT}

21 Disney's showmanship served corporate interests so well that cooperation with outside companies expanded well beyond the confines of Disneyland to the New York World Fair of 1965-1966, where Disney's Imagineers (the Disney corporation's term for park designers) designed four pavilions-three of which were funded by corporations (the fourth, by the State of Illinois). Upon the fair's closure, all pavilions were repatriated to Disneyland, providing for the park's cheap and rapid development. ${ }^{32}$

Disney's work at the fair was to set a precedent for the funding of parks and attractions, with development and construction costs gradually passed on to "sponsors," now forking out between 80 to $90 \%$ of the funds for the attractions of EPCOT. Developed in close cooperation with large American corporations, the " Experimental Prototype Community of Tomorrow" was designed as a kind of permanent world fair where Disney hoped to serve as a "middleman" between consumers and faceless conglomerates suffering from a trust deficit (for a complete list of "primary sponsors," see table $\left.n^{\circ} 2\right) .{ }^{33}$ As former president of Imagineering Marty Sklar explains:

The whole idea [behind EРCOT] was Walt would travel around to the great laboratories of American industry, the GE labs, the Sarnoff labs that were RCA, DuPont, Ford, and IBM. Every time Walt would come to one of those labs they'd trot out the latest thing they were working on. Quite often they'd have nothing to do with products they were selling, and Walt would say, "When can I buy a product based on that technology?" They'd look at him and say, "We don't know if the public is interested in this." Walt came to think that he could be a middle-man between industry and the public-showcasing and demonstrating products and new ideas. Really that's how EPCOT started to evolve. [...] [Industry leaders would say:] "Look, the public doesn't trust what industry tells them, they don't trust what government tells them, but they all trust Mickey Mouse. You people have a role." ${ }^{34}$

Against a payment of at least 35 million dollars (but sometimes twice that amount), participants were given made-to-measure pavilions to educate the public on significant contemporary issues in the areas energy, transportation, food, or communicationsmore often than not reflecting the interests of corporations and turning the Disney company into their more or less willing mouthpiece. Exxon's now-defunct Universe of Energy was thus generally dismissive of renewable energies (not to say entirely silent on global warming), while Kraft's (now Chiquita's) Living with the Land presents the future of agriculture as a high-tech, dirt-free venture, mostly dependent on corporate innovations. ${ }^{35}$

Table ${ }^{\circ} 2$ : List of EPCOT's “primary sponsors"

\begin{tabular}{|l|l|}
\hline Spaceship Earth (1982-present) & $\begin{array}{l}\text { Bell systems (1982-1984) } \\
\text { AT\&T (1984-2004) } \\
\text { Siemens AG (2004-present) }\end{array}$ \\
\hline World of Motion (1982-1996) & General Motors (1982-1996) \\
\hline
\end{tabular}




\begin{tabular}{|l|l|}
\hline The Land (1982-present) & $\begin{array}{l}\text { Kraft Foods (1982-1992) } \\
\text { Nestlé (1993-2009) } \\
\text { Chiquita (2011-present) }\end{array}$ \\
\hline The American Adventure (1982-present) & $\begin{array}{l}\text { Coca-Cola (1982-1998) } \\
\text { American Express (1982-2002) }\end{array}$ \\
\hline Universe of Energy (1982-2017) & ExxonMobil (1982-2004) \\
\hline Horizons (1983-1999) & General Electric (1983-1999) \\
\hline Journey into Imagination (1983-present) & Kodak (1983-1998) \\
\hline The Living Seas (1986-present) & United Technology (1986-2001) \\
\hline Wonders of Life (1989-2007) & MetLife (1989-2007) \\
\hline Test Track (1999-present) & $\begin{array}{l}\text { General Motors (1999-2012) } \\
\text { Chevrolet (2012-present) }\end{array}$ \\
\hline Mission: Space (2003-present) & $\begin{array}{l}\text { Hewlett Packard (2003-2015) } \\
\text { Hewlett Packard Enterprise (2015-present) }\end{array}$ \\
\hline
\end{tabular}

Compiled from Koenig, Realityland.

EPCOT's considerable sponsorship fees meant that the participants' prominence in the park's environment was increased considerably, should it be only because the pool of sponsors was now reduced to a handful of mega-corporations only-each the exclusive representative a major field of US industry. Some of Disneyland's historical participants (Bell, GE, Kodak or Coca-Cola) expanded their presence to EPCOT, while a few newcomers (GM, ExxonMobil, United Technologies or Metlife) were brought in. The situation was somewhat different at World Showcase: while funding was initially sought directly from national governments, the majority of national pavilions ended up funded by business consortiums from the countries represented. ${ }^{36}$

The unprecedented sums expected from Exxon and other sponsors also meant that their participation alone largely determined the park's coming into existence, hence their considerable influence over the attractions' contents and "subjective" treatment of facts, as one Imagineer regrets. ${ }^{37}$ While initially adamant that the shows were not "propaganda," ${ }^{38}$ Marty Sklar has recently come to acknowledge that "we were undoubtedly very naïve about how many suggestions they [corporate sponsors] would have-and how vocally they argued for their point of view. [...] Let's just say there were a number of "facts" we thought could be more objective." ${ }^{39}$ That the Disney company came to be so reliant on outside corporations for EPCOT's creation is hardly a surprise, since the project was originally intended if not as a park, at least as a "showcase for the American free enterprise system" (loaded rhetoric at the time of the Cold War). As Walt Disney declared in his 1966 "ЕPCOT film":

We think the need is for starting from scratch on virgin land and building a special kind of new community. So that's what EPCOT is: an Experimental Prototype Community that will always be in the state of becoming. 
[A] project like this is so vast in scope that no one company alone could make it a reality. But if we can bring together the technical know-how of American industry and the creative imagination of the Disney organization, I'm confident we can create-right here in Disney World-a showcase to the world of the American free enterprise system.

This televised address to the people of Florida was designed to sway the state's lawmakers into adopting a law presented as vital for the project's completion-one that would grant Disney with a private government, complete with powers normally held by Florida counties and cities. Another example of how Disney's "showmanship" allowed the company to rally both corporate and government support by weaving "grand narratives" of technological progress, EPCOT was at the time of the address conceptualized as a real, futuristic community of 20,000 inhabitants. Drawing directly from Disneyland's hub-and-spoke layout, EPCOT was thus to serve as test-market for the very corporations behind the city's innovative transport, building and communication technologies. While ultimately not completed in the form originally presented by Disney, this grand narrative proved enough to secure the cooperation of Florida legislators, who overwhelmingly supported the adoption of Disney's proposed "Reedy Creek Improvement District Act." ${ }^{40}$ Just as importantly, Disney's tales of progress through private initiative helped secure the technical cooperation of four industrial and technological giants in the overall design and construction of not just EPCOT but of the entire Disney World resort-a gigantic undertaking twice the size of Manhattan island, with US Steel, Monsanto, RCA Systems and Aerojet General Corporation developing new technologies for prefabricated construction, communication networks, or innovative trash collection systems. ${ }^{41}$

Keen to publicize their involvement in EPCOT, those corporations came to adopt Disney's utopian rhetoric, testifying (if only publicly) to the persuasiveness of Disney's vision for a better future driven by private corporations. This is especially apparent in the following sentences, excerpted from a 1969 press release published upon the start of Disney World's construction-“a major step toward the realization of Walt Disney's master plan" and "his concept for the Experimental Prototype Community of Tomorrow," in Disney C.E.O. Donn Tatum's words. ${ }^{42}$ Drawing an explicit connection between the Disney corporation, American industry, and the onward march of progress, Edward J. Bock, Monsanto's president and CEO thus stated:

The late Walt Disney was a man who always recognized the constant emergence of exciting ideas and products of American industry. He knew, also, that when such ideas and products were introduced in an appropriate environment, new elements of a better life for millions of people would be the inevitable outcome. [...]

To us, this is a challenging relationship. Just as the Disney organization is readying itself for the world of tomorrow, so are we at Monsanto. As partners, I feel sure our mutual interests can be furthered. [...] We look forward, therefore, to Walt Disney World becoming an adventurous research and development "laboratory" for our company. ${ }^{43}$

Much in the same spirit, RCA's Chase Morsey likewise declared:

Looking ahead the total system is expected to contribute to basic improvements in education, health, safety, utility operations, municipal government, transportation, and recreation. Over the full life of the program, there will evolve for the citizens of EPCOT a vivid picture of what electronics can do for life in the $21^{\text {st }}$ century. [...] We take it as a privilege to work with the Disney organization in a project which holds so much promise for the future of human society. ${ }^{44}$ 


\section{Concluding remarks: Disney Theme Parks and the Political Economy of the Media} reliant on outside companies, whose contribution no longer represented a source of extra revenue but became central to the park's contents and business model. However, there is now every indication that the system of partnerships has come to its end. Nine of EPCOT's original "participants" have failed to renew their sponsorships of attractions over the last decade, leaving only four official sponsors in the park-General Motors, now represented by its Chevrolet subsidiary, Hewlett Packard, Siemens, and Chiquita. As some Imagineers readily admit, many pavilions were vanity projects for their sponsors' CEOs, to the effect that sponsorships were often nixed upon the latter's retirements. What's more, the pavilions' benefits were hard to measure and, if anything, never seemed quite worth their initial costs. ${ }^{45}$

Also, while the parks' environments have for more than sixty years now been carefully calibrated to encourage consumption among visitors, Disney's formula has proved not entirely foolproof-as famously demonstrated by the economic woes of Disneyland Paris. The French park's troubles have resulted not so much form low visitor turnout (only marginally below initial projections) as from disappointing per-capita sales in the park's many shops and restaurants. Indeed, using their astounding (and until now unparalleled) success at Tokyo Disneyland as an indication of their appeal on foreign markets, Disney managers had mistakenly come to believe that demand for Disney merchandise was universal, in complete disregard of the Europeans' thriftier spending habits. ${ }^{46}$

31 Yet, beyond the shopping patterns of individual visitors lie larger scale issues: the parks' systematic promotion of consumption and free-market competition suggests that parks (like much of the media) serve functions essential to capitalism itself. Over the years, the Disney company has made itself something of an unavoidable meeting point between the country's corporations and the general public, shedding light on features and processes central to the media's role in a capitalist economy-as notably argued by proponents of the political economy of the media. ${ }^{47}$ First identified in the pioneering work of economist Dallas Smythe, such features and processes notably include synergy, audience commodification, audience labor, and, finally, the "consciousness industry."

Synergy (and its corollaries, diversification, concentration, and integration) has surely become the most outstanding and discussed of all of the Disney corporation's modes of operation, ${ }^{48}$ with the park acting as the catalyst for the closer integration of the company's various business operations. Walt's entry in the theme park business prompted the studio to diversify its lines of business and expand horizontally to other media (such as television), and vertically to non-media sectors (such as retail or service), allowing the company to grow into "a sort of Tennessee Valley Authority of leisure and entertainment" ${ }^{49}$ and now the world's second largest media conglomerate. Disney synergy occurs not just within (with the cross-promotion of transmedia franchises from one media platform to another) but also without, with skills and technology transfers from the outside in and vice-versa. From the outside in, with lessees and sponsors extending their help and expertise in the studio's first step into the service industry, the creation of location- or theme-appropriate content for 
Disneyland's or EPCOT's attractions, or even the use and development of proprietary technologies in the parks. ${ }^{50}$ From the inside out, with the Disney company now in the business of showcasing and repackaging corporations, or even training outside employees to the parks and hospitality industries' highest service standards. ${ }^{51}$

Yet another way in which parks fulfill media functions otherwise essential to industry in a capitalist economy is by selling and "producing audiences, en masse and in specific demographically desirable forms, for advertisers" ${ }^{52}$-a process first identified as audience commodification by Smythe. ${ }^{53}$ Far from the media's end product, content fulfills purely instrumental functions and serves merely as "an inducement (gift, bribe or 'Free lunch') to recruit potential members of the audience and to maintain their loyal attention." ${ }^{54}$ While participant affairs now represent only a marginal aspect of the parks' business model, Disney was initially quick to capitalize on corporations' interest in using parks as yet another advertising channel, making their contribution crucial to Disneyland's or EPCOT's overall feasibility and success.

Somewhat anticipating later debates about online media, prosumerism, and the blurring of labor-leisure boundaries, ${ }^{55}$ Smythe elaborated that as audiences are sold to corporations, so are they put to work. Maintaining that "audiences' exposure to advertising should be considered labor that added value to the audience commodity," audience labor was thus to be considered as the inevitable corollary of the audience commodity. ${ }^{56}$ That corporate exhibitions were originally branded as "free" (when other attractions required admission tickets, before the adoption of all-inclusive entry tickets in 1982) paradoxically points to their transactional nature, allowing the audience's attention time to serve as payment for their educational or entertainment value ${ }^{57}$ Yet audience labor in the parks far exceeds what has only recently been termed "the attention economy" and extends all the way to an underlying cognitive or emotional economy. Much in the way that the employees' work is presented as mere play ${ }^{58}$ so are visitors required to perform some tasks-such as exhibiting appropriate attitudes or feelings, with audience's emotions literally put "on show" and a key ingredient to the entertainment on offer in the parks. ${ }^{59}$

While already discussed at some length, the ideological function of the parks might likewise be best understood within the framework of Smythe's political economy of the media-a role that Smythe refers to as "the consciousness industry," that is to say the "pervasive reinforcement of the ideological basis of the capitalist system" for the production of "audiences prepared to be dutiful consumers." ${ }^{60}$ In their efforts to promote corporations, parks likewise serve an overt ideological agenda especially conducive to the consumption of industry's products, that is to say: the promotion of capitalism as an expression of American genius (as suggested by Main Street U.S.A.'s very name), the presentation of corporations as engines of progress, and their naturalization as the inevitable product of the free enterprise system. Yet, parks usually operate as closed, harmonious, and tightly regulated markets (the product of Disney's "invisible hand"), sometimes even shielded from legal obligations otherwise imposed on competitors. ${ }^{61}$ Such ambiguities (namely, that monopolistic or governmentsupported business operations might serve as valid examples of the United States' "free enterprise system") might help present the public with a more readily acceptable version of free-market capitalism-one apparently free of cut-throat competition and other destructive excesses. Disney's program for the voluntary cooperation of benevolent conglomerates likewise helps suggest that private companies are best left to 
their own devices, exempt from red-tape, or even acting as substitutes to government itself. Yet, as the product of allegedly mutually advantageous arrangement between the Florida state and the California studio, Disney's private government built on earlier patterns of business-government cooperation (which the Disney studio experienced firsthand, as one of the nation's foremost suppliers of World War II propaganda), expanding it to areas well beyond the Cold War-era Military-Industrial Complex. Maybe even more significantly, Disney's rationale for EPCOT appealed to 1920s notions of "business progressivism" and "associationalism" of the kind supported by Herbert Hoover-in which self-regulating businesses would contribute expertise in the areas of "scientific rationalization" and "social engineering" and essentially form a private government conducive to "national reform, greater stability, and steady expansion." ${ }_{62}$ Much in the way that Main Street was a vision of Gilded Age America tinged with nostalgia, so was EPCOT's vision not of the future, but of the past.

\section{BIBLIOGRAPHY}

Baudrillard, Jean. Simulations. Los Angeles: Semiotext(e), Inc., 1983.

Blake, Peter. “Mickey Mouse for Mayor.” New York Magazine, February 7, 1972.

Bryman, Alan. Disney and His Worlds. London: Taylor \& Francis, 2007.

--- The Disneyization of Society. London: Sage Publications, 2004.

“Case Studies | Client Impact | Disney Institute." <accessed February 27, 2018. https://

disneyinstitute.com/client-impact/case-studies/.>

Certeau, Michel de. The Practice of Everyday Life. Translated by Steven Rendall. Berkeley:

University of California Press, 1984.

Clément, Thibaut. Plus vrais que nature. Les parcs Disney, ou l'usage de la fiction de l'espace et le paysage. Paris: Presses de la Sorbonne Nouvelle, 2016.

Davis, Sally. “Should We Let Disney Redesign LA?” Los Angeles, July 1974.

DeCordova, Richard. “The Mickey in Macy's Window: Childhood, Consumerism, and Disney

Animation." In Disney Discourse: Producing the Magic Kingdom, edited by Eric Smoodin, 203-12. New York: Routledge, 1994.

Eco, Umberto. Travels in Hyper Reality: Essays. New York: Harcourt Brace Jovanovich, 1986.

Fisher, Eran. "How Less Alienation Creates More Exploitation? Audience Labour on Social Network Sites.” TripleC: Communication, Capitalism \& Critique. Open Access Journal for a Global Sustainable Information Society 10, no. 2 (May 25, 2012): 171-83.

Fjellman, Stephen M. Vinyl Leaves: Walt Disney World And America. Boulder: Westview Press, 1992.

Foglesong, Richard E. Married to the Mouse: Walt Disney World and Orlando. New Haven: Yale University Press, 2003. 
Fuchs, Christian. "Dallas Smythe Today - The Audience Commodity, the Digital Labour Debate, Marxist Political Economy and Critical Theory. Prolegomena to a Digital Labour Theory of Value." TripleC: Communication, Capitalism \& Critique. Open Access Journal for a Global Sustainable Information Society 10, no. 2 (September 19, 2012): 692-740.

- - . "Digital Prosumption Labour on Social Media in the Context of the Capitalist Regime of Time.” Time \& Society 23, no. 1 (March 1, 2014): 97-123.

"Labor in Informational Capitalism and on the Internet." The Information Society 26, no. 3 (April 30, 2010): 179-96.

Golberger, Paul. "Mickey Mouse Teaches the Architect.” New York Times, October 22, 1972. Gruen, Victor. Shopping Towns USA: The Planning of Shopping Centers. New York: Reinhold Pub. Corp, 1960.

Hawley, Ellis W. "Herbert Hoover, the Commerce Secretariat, and the Vision of an "Associative State,' 1921-1928.” The Journal of American History 61, no. 1 (June 1974): 116-40.

Hench, John, and Peggy Van Pelt. Designing Disney. New York: Disney Editions, 2003.

"History: 1950s." AdAge.com, September 15, 2003. http://adage.com/article/adageencyclopedia/history-1950s/98701/. <accessed June 5, 2018>

Hochschild, Arlie Russell. The Managed Heart: Commercialization of Human Feeling. Berkeley: University of California Press, 1983.

Huws, Ursula. "The Underpinnings of Class in the Digital Age: Living, Labour and Value." Socialist Register 50, no. 50 (October 28, 2013).

Jenkins, Henry. Textual Poachers: Television Fans \& Participatory Culture. Routledge, 1992.

King, Margaret J. “Disneyland and Walt Disney World: Traditional Values in Futuristic Form." The Journal of Popular Culture 15, no. 1 (June 1981): 116-40.

Koenig, David. Realityland: True-Life Adventures at Walt Disney World. Irvine: Bonaventure Press, 2007.

Lindquist, Jack, and Melinda J. Combs. In Service to the Mouse: My Unexpected Journey to Becoming Disneyland's First President: A Memoir. Chapman University Press/Neverland Media, 2011.

Mannheim, Steve. Walt Disney and the Quest for Community. Ashgate Publishing, 2003.

Marin, Louis. “Dégénérescence Utopique : Disneyland.” In Utopiques : Jeux d'espace, 297-324. Paris: Editions de Minuit, 1973.

Marling, Karal Ann. “Imagineering the Disney Theme Parks.” In Designing Disney's Theme Parks: The Architecture of Reassurance, edited by Karal Ann Marling, 29-177. New York: Rizzoli / Flammarion, 1998.

"Meetings at Disney | About." https://disneyinstitute.com/about/meetings-at-disney/.<accessed June 5, 2018>

Mosco, Vincent. The Political Economy of Communication: Rethinking and Renewal. The Media, culture \& society series. - London : Sage, 1994. London: Sage Publications, 1998.

Mosco, Vincent, and Janet Wasko. The Political Economy of Information. Studies in communication and society. Madison: University of Wisconsin Press, 1988.

Olsen, Joshua. Better Places, Better Lives: A Biography of James Rouse. Urban Land Institute, 2014.

Onosko, Tim. "Tomorrow Lands.” OMNI, September 1982. 
Packman, Hollie Muir, and Fred L. Casmir. "Learning from the Euro Disney Experience." International Communication Gazette 61, no. 6 (December 1, 1999): 473-89.

Pallant, Chris. Demystifying Disney: A History of Disney Feature Animation. New York: Bloomsbury Academic, 2011.

Parfitt, Dave. "Marty Sklar Discusses Working With And For Walt Disney | The DIS Unplugged Disney Blog." Disney Unplugged, March 22, 2011. http://www.disunplugged.com/2009/12/18/ marty-sklar-discusses-working-with-and-for-walt-disney/. <accessed June 5, 2018>

Sklar, Marty. Dream It! Do It!: My Half-Century Creating Disney's Magic Kingdoms. 3rd Printing edition. New York: Disney Editions, 2013.

Smoodin, Eric. Disney Discourse: Producing the Magic Kingdom. London: Routledge, 1994.

Smythe, Dallas W. "Communications: Blindspot of Western Marxism." Canadian Journal of Political and Social Theory 1, no. 3 (December 30, 1977): 1-27.

---. Counterclockwise. Boulder, CO: Westview Press, 1994.

---. Dependency Road: Communications, Capitalism, Consciousness, and Canada. Norwood, NJ: Ablex Publishing Corporation, 1981.

-_-. "On the Political Economy of Communications." Journalism Quarterly 37, no. 4 (1960): 56372.

Strodder, Chris. The Disneyland Encyclopedia: The Unofficial, Unauthorized, and Unprecedented History of Every Land, Attraction, Restaurant, Shop, and Event in the Original Magic Kingdom. Santa Monica: Santa Monica Press, 2008.

Swagler, Roger. "Evolution and Applications of the Term Consumerism: Theme and Variations." The Journal of Consumer Affairs 28, no. 2 (1994): 347-60.

Telotte, J.P. The Mouse Machine: Disney and Technology. Champaign: University of Illinois Press, 2008.

Thomas, Bob. Walt Disney: An American Original. New York: Disney Editions, 1994.

Van Maanen, John, and Gideon Kunda. "Real Feelings: Emotional Expressions and Organization Culture." Research in Organizational Behavior 11 (1989): 43-102.

Walt Disney Productions. "Vast Walt Disney World Site to Become the Vacation Kingdom of the World." Walt Disney World Press Kit. Orlando, Florida, April 30, 1969. The Vacation Kingdom of the World. http://www2.stetson.edu/library/specialcollections_presskit.php.

Wasko, Janet. “Challenging Disney Myths." Journal of Communication Inquiry 25, no. 3 (July 1, 2001): 237-57.

--_. "The Study of the Political Economy of the Media in the Twenty-First Century." International Journal of Media \& Cultural Politics 10 (September 1, 2014).

-_- Understanding Disney: The Manufacture of Fantasy. Oxford: Polity, 2001.

WED Enterprises. "Disneyland: Where You Leave Today ... and Visit the World of Yesterday and Tomorrow.” Report. Burbank, January 1, 1953. 159. Harrison “Buzz” Price Papers. http:// stars.library.ucf.edu/buzzprice/159. <accessed June 5, 2018>

--- Safety and Operations Manual: You're Onstage at Disneyland. Burbank: WED Enterprises, 1962. http://matterhorn1959.blogspot.com/2007/02/sop-saturday-on-sunday-youre-onstage-at.html. $<$ accessed June 5, 2018> 
. The Story of Disneyland, with a Complete Guide to Fantasyland, Tomorrowland, Adventureland, Frontierland, Main Street U.S.A. Burbank: WED Enterprises, 1955. http://www.disneybymark.com/ 1955-Guidebook-DisneybyMark.pdf. <accessed June 5, 2018>

Wright, Alex. The Imagineering Field Guide to Magic Kingdom at Walt Disney World. New York: Disney Editions, 2009.

\section{ENDNOTES}

1. Disney now owns and runs twelve parks around the globe, with six parks in the United States alone. (This includes two parks at Disneyland Resort, Anaheim, California, and four at Walt Disney World, Orlando, Florida. Japan, France and now China each have two Disney parks). Disneyland provided the basis for all of Disney's flagship Magic Kingdom-style parks, first at Walt Disney World's Magic Kingdom (open 1971) and later, Tokyo Disneyland (1981), Disneyland Paris (1992), Hong Kong Disneyland (2005), and Shanghai Disneyland (2016). The first park to consciously deviate from Disneyland's tried-and-true formula was EPCOT Center (Walt Disney World, 1982) - a kind of permanent world fair, whose broad themes include technology (Future World) and international cooperation (World Showcase).

2. Alan Bryman, The Disneyization of Society (London: Sage Publications, 2004), 159.

3. For a literature review on Disney theme parks' glorification of private corporations, see: Alan Bryman, Disney and His Worlds (London: Taylor \& Francis, 2007), 113-26.

4. For examples of fan-oriented books, see: John Hench and Peggy Van Pelt, Designing Disney (New York: Disney Editions, 2003); Marty Sklar, Dream It! Do It!: My Half-Century Creating Disney's Magic Kingdoms,(New York: Disney Editions, 2013); Alex Wright, The Imagineering Field Guide to Magic Kingdom at Walt Disney World (New York: Disney Editions, 2009).

For examples of internal documents collected by fans or held in university archives, see: WED Enterprises, Safety and Operations Manual: You're Onstage at Disneyland (Burbank: WED Enterprises, 1962), http://matterhorn1959.blogspot.com/2007/02/sop-saturday-on-sunday-youre-onstageat.html; WED Enterprises, "Disneyland: Where You Leave Today ... and Visit the World of Yesterday and Tomorrow" (Burbank, January 1, 1953), 159, Harrison "Buzz" Price Papers, http:// stars.library.ucf.edu/buzzprice/159.

5. The Walt Disney Company, a notoriously secretive company, has now closed its archives to outside researchers as well as closely monitors what its employees are allowed to say in public. In the absence of better alternatives and direct access to primary sources, works of fan scholarship have proved an invaluable and generally reliable source of information, giving credence to Henry Jenkins's remarks that fans are indeed "the true experts" in the effort of "knowledge production" on popular culture. The existence of such sources, incidentally, testifies to the agency and criticality of park users and, most prominently, park fans - far from Eco's (and, incidentally, many other critics') earlier visions of Disneyland as a "place of total passivity" where visitors behave like "robots." While the paper's primary focus is on the parks' design and business, the intended role of audiences will be explored more specifically in the latter part of the discussion. See: Henry Jenkins, Textual Poachers: Television Fans \& Participatory Culture (Routledge, 1992), 86; Umberto Eco, Travels in Hyper Reality: Essays (New York: Harcourt Brace Jovanovich, 1986), 48.

For examples of all three kinds of fan scholarship works mentioned above, see: Jack Lindquist and Melinda J. Combs, In Service to the Mouse: My Unexpected Journey to Becoming Disneyland's First President: A Memoir (Chapman University Press/Neverland Media, 2011); Chris Strodder, The Disneyland Encyclopedia: The Unofficial, Unauthorized, and Unprecedented History of Every Land, Attraction, Restaurant, Shop, and Event in the Original Magic Kingdom (Santa Monica: Santa Monica 
Press, 2008); David Koenig, Realityland: True-Life Adventures at Walt Disney Worl d (Irvine: Bonaventure Press, 2007).

6. This distinction goes to the Fleischer Studio, whose Felix the Cat spearheaded the studio's licensing efforts. See: Chris Pallant, Demystifying Disney: A History of Disney Feature Animation (New York: Bloomsbury Academic, 2011), 14.

7. Bob Thomas, Walt Disney: An American Original (New York: Disney Editions, 1994), 106-8.

8. J.P. Telotte, The Mouse Machine: Disney and Technology (Champaign: University of Illinois Press, 2008), 98.

9. Disney's entry into merchandising and, more specifically, the sale of goods marketed toward children points to transformations typical of the Great Depression, when corporations and manufacturers were forced to create new markets to subsist. Thanks to its efforts, Disney proved a leading contributor to children's entry into the marketplace - as consumers, if not as workers. (Child labor in the United States was only permanently eradicated by law in the late 1930s, with the Fair Labor Standards Act of 1938).

10. In a 1931 letter to Carl Solloman, Roy Disney - Walt's brother - thus notably wrote: "The sale of a doll to any member of a household is a daily advertisement in that household for our cartoons and keeps them all 'Mickey Mouse minded'. [...] We feel we should publicize our character from every angle and accept from every opportunity." See: Richard DeCordova, "The Mickey in Macy's Window: Childhood, Consumerism, and Disney Animation," in Disney Discourse: Producing the Magic Kingdom, ed. Eric Smoodin (New York: Routledge, 1994), 205. Most remarks presented here on the Mickey Mouse Clubs are drawn from DeCordova's illuminating essay on the topic.

11. In 1953, the park was slated to open with a total of 73 rides, exhibitions, and attractions, and 93 shops, restaurants, and refreshment stands (WED Enterprises, "Disneyland: Where You Leave Today.") A 1955 map of the park brings those numbers down to 53 and 56, respectively. See: WED Enterprises, The Story of Disneyland, with a Complete Guide to Fantasyland, Tomorrowland, Adventureland, Frontierland, Main Street U.S.A. (Anaheim, Calif., 1955), http:// www.disneybymark.com/1955-Guidebook-DisneybyMark.pdf.

12. Bryman, Disney and His Worlds, 159.

13. Hench and Van Pelt, Designing Disney, 63.

14. By this expression, one refers to the process by which emotions are sold on the marketplace. As such, it is especially related to "emotional labor," i.e., when staff is required by management to convey specific feelings when carrying out specific tasks. For a discussion of emotional labor, see: Hochschild 1983. For an analysis of emotional labor in Disney parks, see: John Van Maanen and Gideon Kunda, "Real Feelings: Emotional Expressions and Organization Culture," Research in Organizational Behavior 11 (1989): 43-102.

15. WED Enterprises, You're Onstage at Disneyland.

16. Consumerism is here used in the sense of the Oxford English Dictionary: "Name given to a doctrine advocating a continual increase in the consumption of goods as the basis of a sound economy." The Webster Dictionary provides another useful definition: "a preoccupation with and an inclination toward the buying of consumer goods."

In a chapter devoted to the topic, Alan Bryman identifies three components to consumerism in Disney theme parks: 1 . parks are environment meant to maximize consumption opportunities; 2 . they suggest that self-accomplishment is possible through purchases that support one's sense of identity and desired lifestyle; and 3. they present shopping as a form of entertainment.

As Roger Swaggler notes, the notion of consumerism has in time come to bear negative undertones (as "excessive" or "soulless"), and so have early critics of Disney parks like Umberto Eco suggested that, by blurring the line between "real" and fake," Disneyland "falsif[ies] our will to buy" and comes across as the "quintessence of the consumer ideology"

However, new understandings of popular audiences and cultural practices in the wake of de 
Certeau have since dismissed consumption as necessarily naïve or passive and made it another possible avenue for the expression of the park visitors' agency. In a widely influential passage from The Practice of Everyday Life, Certeau thus presents consumption as creative process - a mode of production in its own right, which "manifest[s] itself ... through its ways of using the products imposed by a dominant economic order," as well as a tactical activity which allows users to pursue their own ends and interests.

See: Bryman, Disney and His Worlds, 113-26; Roger Swagler, "Evolution and Applications of the Term Consumerism: Theme and Variations," The Journal of Consumer Affairs 28, no. 2 (1994): 34760; Eco, Travels in Hyper Reality, 43; Michel de Certeau, The Practice of Everyday Life, trans. Steven Rendall (Berkeley: University of California Press, 1984), xii-xiii.

17. Disney's vision of progress through technology comes loaded with a good dose of nostalgia for the values of small-town Middle America - so much so that Margaret King speaks of "traditional values in futuristic form." See: Margaret J. King, "Disneyland and Walt Disney World: Traditional Values in Futuristic Form," The Journal of Popular Culture 15, no. 1 (June 1981): 116-40.

18. To drive its point even further, Disneyland Paris's Main Street arranges its commercial environment into a sequence, so that as visitors walk down the street, the bicycle shop later gives way to a car dealership, while gas lamps slowly transition to electric lighting. In other words, walking down Main Street allows visitors to follow the linear and bump-free path of technological progress - one essentially associated with business and economic development. Disneyland Paris's Emporium likewise features a stained glass dome, adorned with the portraits of Thomas Edison, George Eastman, and assorted inventor-entrepreneurs, tying together the themes of entrepreneurship, technological progress, and consumption.

19. Wright, The Imagineering Field Guide to Magic Kingdom, 22.

20. Wright, The Imagineering Field Guide to Magic Kingdom, 30.

21. To some extent, those deals drew from Disney's experience with $A B C$ - a partnership critical to Disneyland's opening. The network took a minority stake in exchange for Disney's first regular television program, allowing Walt Disney to use his Disneyland Show to advertise his soon-toopen park to television audiences across the country.

22. As a 1953 training manual notes, "Most of Main Street's shops are operated by companies that were business pioneers at the turn of the century, and all buildings and interiors are designed to fit the decor of this era." WED Enterprises, "Disneyland: Where You Leave Today," 7.1.

23. As the above-quoted manual explains: "The Disney Team is much larger than just the Disney organizations. In addition, we have over sixty-eight other firms playing a vital part in our team effort to bring happiness to our guests. Some are small, specialized individual operators; some are huge companies such as Swift \&Co. - the Bank of America - United Paramount Theater (which you hear as UPT) - Carnation - Richfield - General Dynamics - Crane - and many others." Most individual lessees were gone by the end of the decade. See: WED Enterprises, "Disneyland: Where You Leave Today," 1.5.

24. In this area, the park suffered a few misfires, as shops - at least initially - were "operated first and foremost as part of the [Disneyland] show," with only limited concern for profitability (Koenig, Realityland, 109). The independently-run lingerie, china or shoe stores which Walt, in a nod to the real thing, insisted his Main Street have, were thus gone after a few years. Still, the same logic applied at Orlando's Magic Kingdom park (open 1971), where the antiques shop made $\$ 100,000$ a year but allegedly spent ten times more.

See: Karal Ann Marling, "Imagineering the Disney Theme Parks," in Designing Disney's Theme Parks: The Architecture of Reassurance, ed. Karal Ann Marling (New York: Rizzoli / Flammarion, 1998), 90; Koenig, Realityland, 111.

25. Those prohibitively expensive participant contracts were seldom welcome by the parks' purchasing department, which frequently noticed that suppliers, in the absence of competitive bids, typically overcharged Disney: “'Operation versus Participant Affairs is like day and night,' 
agreed Bob Ziegler, who worked both sides. 'Foods didn't want to be told they had to use Coke, not Pepsi.' [...] [Then head of the purchasing department Howard] Roland thought that, by eliminating competitive bids, the participant contracts allowed suppliers to take advantage of Disney. 'We constantly fought that battle,' Roland said. 'We could only use Coca-Cola, Oscar Mayer hot dogs, and Borden milk, so sometimes the sponsors made up their sponsor fees in overcharges."' (Koenig, Realityland, 164-65)

26. The least furnished of all lands upon Disneyland's opening in 1955 (possibly because the farthest removed from Disney's usual brand of movies), Tomorrowland stood to benefit the most from corporate sponsorships and free exhibitions. As described in 1953, the land was slated to open with no less than six corporate exhibitions (seven, including Monsanto's House of Tomorrow, originally located slightly outside Tomorrowland). Those were: Monsanto's Hall of Chemistry, whose "display shows how chemistry affects every day living - in food, clothing, shelter, and health today - and some of the possibilities chemistry has in store tomorrow; the Monsanto Home of the Future, the "World's most-remarkable all-plastic house"; the Kaiser Aluminum \& Chemical Corp, "an educational and entertaining display giving the complete story of aluminum - from beginning to the present - and into the future", Crane Co's "display showing the 'Bathroom of Tomorrow' and laundry room of the future"; or Richfield Oil Corp's "The World Beneath Us" - a show including "a cartoon story (produced by W[alt] D[isney] P[roductions]) of the development of the earth; a diorama model of the entire Los Angeles basin; and a working model of an underground oil reservoir."

See: WED Enterprises, "Disneyland: Where You Leave Today," 6.8-6.9.

27. Koenig, Realityland, 153.

28. Such was the association between television, advertisement, and consumerism that Robert Sarnoff, president of NBC, notably declared in 1956: "The reason we have such a high standard of living is because advertising has created an American frame of mind that makes people want more things, better things, and newer things." As explained in footnote 21, Walt Disney understood the commercial promises of television all too well and, in 1954, branched into the medium mostly to advertise his soon-to-open theme park.

See: “History: 1950s," AdAge.com, September 15, 2003, http://adage.com/article/adageencyclopedia/history-1950s/98701/.

29. Much in the way that the names of products were directly incorporated into television series titles (such as General Electric Theater, 1953-62, or Chevrolet on Broadway, 1956), so did attractions prominently feature the name of their corporate sponsors (for example: "Adventure Thru Inner Space, presented by Monsanto").

30. In the words of Victor Gruen, an architect and key promoter of the shopping mall in 1950s and 1960s America, "merchandising" means "the selection and location of tenant types or, if possible, specific tenants on the renting plan ... to create a situation in which each member of the retail entity - the owner, the tenant, and the shopper - functions in a manner that benefits each of the others." As such, it represents "a rare occurrence in our free enterprise economy - the banding together of individual businesses in cooperative fashion with the aim of creating greater commercial effectiveness through unified endeavor." See: Victor Gruen, Shopping Towns USA: The Planning of Shopping Centers (New York: Reinhold Pub. Corp, 1960), 131, 139.

31. As the table suggests, other sectors of industry represented in Disneyland included air travel (TWA, McDouglas), consumer electronics, and information and communications technologies (Wurlitzer, Bell, General Electric).

32. As Richard Foglesong notes, those attractions - General Electric's Carousel of Progress, Ford's Magic Skyways, “Pepsi-Cola Presents Walt Disney's 'It's a Small World'-a Salute to UNICEF and the World's Children", and the State of Illinois's Great Moments with Mr. Lincoln - proved a major draw with audiences, collectively attracting $90 \%$ of all visitors to the Fair. Set to the song "There's a Great Big Beautiful Tomorrow," General Electric's Carousel of Progress notably 
consisted in a theater rotating past four stationary audio-animatronic tableaus, all of which featured the same family delighting in the advances of technology, from the early $20^{\text {th }}$ century to the 1960s. See: Richard E. Foglesong, Married to the Mouse: Walt Disney World and Orlando (New Haven: Yale University Press, 2003), 36.

33. By charging "primary sponsors" a minimum of $\$ 35$ million for a ten-year lease, the Walt Disney Company expected the 6 to 10 projected participants to shoulder approximately half of all costs required for the construction of EPCOT. United Technology and Metropolitan Life Insurance paid \$60 and \$72 million for their twelve-year lease on The Living Seas and Wonders of Life pavilions. As Pete Clark, head of corporate sponsorships, explains: "Companies were used to spending money on a single show. [...] The figure-\$35 million for a ten-year contract-we just grabbed out of the air. They would all have a product area, which would be their cost to staff." Koenig, Realityland, 168.

34. Dave Parfitt, "Marty Sklar Discusses Working With And For Walt Disney | The DIS Unplugged Disney Blog,” Disney Unplugged, March 22, 2011, http://www.disunplugged.com/2009/12/18/ marty-sklar-discusses-working-with-and-for-walt-disney/.

35. In both versions of the attraction's script, alternatives to oil are presented as experimental, while solutions for the continued use of oil are emphasized. The 1982 script notably reads: "It's a supply that is not inexhaustible, however, not as the global demand for energy-all kinds of energy-continues to increase. Most countries must depend on the uncertainties of imported oil until the big breakthroughs finally happen. But the world can't simply 'park its cars' or 'turn off its lights' until that day. We must continue to conserve and extend today's energy sources and develop a broad mix of alternatives for the future. Already, current supplies are being stretched through the use of heat-sensing monitors and other new systems which help increase energy conservation. At the same time, special oil recovery techniques are helping to bring older fields back to life."

When the show was refurbished in 1996, it reopened as Ellen's Energy Adventure (after Ellen DeGeneres, the attraction's protagonist). Emphasizing the practicality of oil over other energy sources, the newer script minimizes the depletion of oil reserves: "We're far from running on empty. And we've got some pretty far-out ways of finding more."

36. For a first-hand account of the Disney corporation's efforts to secure funding from national governments, see former president of Disneyland Jack Lundquist's memoir: Lindquist and Combs, In Service to the Mouse.

37. By requiring sponsors to shoulder somewhere between 80 to $90 \%$ of their pavilion's construction costs, the Walt Disney Company left EPCOT's completion dangerously exposed to the corporations' participation. As Imagineer Tony Baxter explains about Exxon: “I remember decisions that were made, such as to go or not to go on the Energy pavilion concept, which was extraordinary and was going to cost a fortune. [...] The thing was, if we lost Exxon, we lost EPCOT. It was that simple. There was no margin for losing anything. It was like the more you got out of a sponsor, the more colossal or stupendous [their pavilion] could be." Koenig, Realityland, 182.

38. Tim Onosko, “Tomorrow Lands," OMNI, September 1982.

39. Sklar, Dream It! Do It!, 178.

40. By the mid-1960s, the urban crisis had become so apparent that, in the absence of significant improvements at the hands of the government (at both the federal or state levels), new avenues opened for private companies to offer solutions to the public problem of unplanned growth. (Sprawl itself resulted in part from federal policies promoting homeownership, with government-subsidized loans, or extending highways, with the Federal-Aid Highway Act, 1956). As a result, Disney's vision for his Experimental Prototype Community of Tomorrow was but one of numerous developments in the area of privately-run and -designed new towns. With many similarities noted between parks and shopping malls, Walt Disney unsurprisingly turned to James Rouse or Victor Gruen for inspiration. Both men had gone from mall-designers and -developers 
to new-town promoters, and hoped that some of the principles behind their successful shopping centers might now be applied to entire, fully functional communities or even decaying downtowns. James Rouse, whose 1967 new town of Columbia was a pioneering effort in that area, thus met with Disney on several occasions to discuss Epcot. Walt Disney likewise proved quite influenced by Gruen's 1964 Heart of our Cities, and so does Epcot bear a striking resemblance with Gruen's proposal for Washington D.C.'s bid for the 1964 World Fair. Both share the same belowground transit and service infrastructures, the same vast green expanses above, as well as the same circular layout.

Public response to Disney's ambitions in the area of urban planning was enthusiastic. Much in keeping with Rouse's celebration of Disneyland as "the greatest piece of urban design in the United States today" (in a 1963 conference at Harvard University), a slew of 1970s newspapers titles proclaimed or asked: "Mickey Mouse for Mayor", "Mickey Mouse Teaches the Architect," or "Should We Let Disney Redesign LA?" This, Disney more or less did at Anaheim, after Walt's grand vision for Epcot died alongside its progenitor (others in the company - starting with his brother Roy, the company's CEO - remained mostly unconvinced). Yet again walking in the footsteps of Gruen and Rouse and taking its cue from Jon Jerde's 1993 Universal CityWalk at Universal City, the Walt Disney Company set out to provide chiefly suburban Anaheim with a downtown of its own. This effort took the form of Downtown Disney (opened 2001), an open-air, pedestrian shopping mall located at the foot of its two theme parks at Disneyland Resort.

For Rouse's and Gruen's influence on Walt Disney, see: Joshua Olsen, Better Places, Better Lives: A Biography of James Rouse (Urban Land Institute, 2014), 240-41; Steve Mannheim, Walt Disney and the Quest for Community (Ashgate Publishing, 2003), xvii.

For newspaper articles discussing Disney theme parks from an urban planning perspective, see: Peter Blake, "Mickey Mouse for Mayor," New York Magazine, February 7, 1972; Paul Golberger, "Mickey Mouse Teaches the Architect," New York Times, October 22, 1972; Sally Davis, "Should We Let Disney Redesign LA?," Los Angeles, July 1974.

41. US Steel was left in charge of developing steel frames and prefabrication techniques for the construction of Walt Disney World's first two hotels, the Contemporary Hotel and the Polynesian Resort. RCA was commissioned a fully integrated computer and communication system called WEDCOMM (Walter E. Disney Communications Oriented Monitoring and Management System) to track events throughout the resort, manage reservations, provide telephone and mobile communications, as well as CCTV - among other functions. Aerojet-General Corporation was tasked with the creation of an automated vacuum waste collection system. Monsanto, for its part, was to help with the somewhat vague task of applying "the technology, research, and expertise of Monsanto" to "numerous other aspects of the Walt Disney World project". See: Walt Disney Productions, "Vast Walt Disney World Site to Become the Vacation Kingdom of the World," Walt Disney World Press Kit (Orlando, Florida, April 30, 1969), 4, The Vacation Kingdom of the World, http://www2.stetson.edu/library/specialcollections_presskit.php.

42. Walt Disney Productions, "Vast Walt Disney World Site to Become the Vacation Kingdom of the World," 3.

43. Walt Disney Productions, "Vast Walt Disney World Site to Become the Vacation Kingdom of the World," 5.

44. Walt Disney Productions, "Vast Walt Disney World Site to Become the Vacation Kingdom of the World," 4.

45. Kraft was the first corporate sponsor to pull out in 1992, soon followed by Coca-Cola, Kodak (both 1988), General Electric (1999), United Technology (2011), American Express (2002), Exxon Mobil (2004), AT\&T (2004), MetLife (2007) and, more recently, Nestlé (2009). General Motors' loyalty, as well as Hewlett Packard's, Chiquita's, and Siemens' recent arrivals, have failed to halt the desertion of EPCOT's original sponsors. As former director of participant affairs Robert Ziegler explains: "Some of those [sponsorships] were pyramids people built in their companies' 
heyday [...] MetLife and UTC [United Technologies Corporation] were there just for hospitality. We didn't use a lot of UTC products, and [MetLife] didn't sell a lot of insurances at Walt Disney World. Few people saw the sponsorship and said, 'Hey, I need some life insurance!"” See: Koenig, Realityland, 321.

46. Hollie Muir Packman and Fred L. Casmir, "Learning from the Euro Disney Experience," International Communication Gazette 61, no. 6 (December 1, 1999): 479-80.

47. For examples, see: Vincent Mosco and Janet Wasko, The Political Economy of Information, Studies in communication and society (Madison: University of Wisconsin Press, 1988); Janet Wasko, "The Study of the Political Economy of the Media in the Twenty-First Century," International Journal of Media \& Cultural Politics 10 (September 1, 2014); Vincent Mosco, The Political Economy of Communication: Rethinking and Renewal. London : Sage, 1994 (London: Sage Publications, 1998); Christian Fuchs, "Dallas Smythe Today - The Audience Commodity, the Digital Labour Debate, Marxist Political Economy and Critical Theory. Prolegomena to a Digital Labour Theory of Value.," TripleC: Communication, Capitalism \& Critique. Open Access Journal for a Global Sustainable Information Society 10, no. 2 (September 19, 2012): 692-740.

48. Janet Wasko, Understanding Disney: The Manufacture of Fantasy (Oxford: Polity, 2001); Janet Wasko, "Challenging Disney Myths," Journal of Communication Inquiry 25, no. 3 (July 1, 2001): 23757.

49. Eric Smoodin, Disney Discourse: Producing the Magic Kingdom (London: Routledge, 1994), 3.

50. For example, the technology for the World Fair's and, later, Disneyland's PeopleMover was inspired by a trip to a Ford factory, which Walt and Imagineer John Hench were invited to tour. The system was developed by adding flat-bottom vehicles to "tracks of powered rollers" to move around ingots of molten steel. See: Hench and Van Pelt, Designing Disney, 23-24.

51. Created in 1994, the Disney Institute turned to providing professional development courses in 2000. Clients include corporations like Volvo, Siemens, the NFL, Chevrolet, or Haagen-Dazs. Training seminars typically take place in its Magic Kingdom resort and purport to allow clients to "take a look at our time-tested customer experience best practices as you explore our business insights firsthand, in our parks and resorts 'living laboratory.' This is a powerful professional development opportunity, to learn how we think and how you could adapt our principles to your own organization." See: "Case Studies | Client Impact | Disney Institute," accessed February 27, 2018, https://disneyinstitute.com/client-impact/case-studies/; "Meetings at Disney | About," accessed February 27, 2018, https://disneyinstitute.com/about/meetings-at-disney/.

52. Mosco, The Political Economy of Communication, 149.

53. Dallas W. Smythe, "On the Political Economy of Communications," Journalism Quarterly 37, no. 4 (1960): 563-72.

54. Dallas W. Smythe, "Communications: Blindspot of Western Marxism," Canadian Journal of Political and Social Theory 1, no. 3 (December 30, 1977): 5.

55. For examples, see: Eran Fisher, "How Less Alienation Creates More Exploitation? Audience Labour on Social Network Sites," Triplec: Communication, Capitalism \& Critique. Open Access Journal for a Global Sustainable Information Society 10, no. 2 (May 25, 2012): 171-83; Christian Fuchs, "Labor in Informational Capitalism and on the Internet," The Information Society 26, no. 3 (April 30, 2010): 179-96; Fuchs, "Dallas Smythe Today"; Christian Fuchs, "Digital Prosumption Labour on Social Media in the Context of the Capitalist Regime of Time," Time \& Society 23, no. 1 (March 1, 2014): 97-123; Ursula Huws, "The Underpinnings of Class in the Digital Age: Living, Labour and Value," Socialist Register 50, no. 50 (October 28, 2013).

56. Wasko, "The Study of the Political Economy," 264.

57. Smythe explains that: "Because audience power is produced, sold, purchased and consumed, it commands a price and is a commodity. [...] You audience members contribute your unpaid work time and in exchange you receive the program material and the explicit advertisements." 
Dallas W. Smythe, Dependency Road: Communications, Capitalism, Consciousness, and Canad a (Norwood, NJ: Ablex Publishing Corporation, 1981), 26, 233.

58. Bryman, The Disneyization of Society, 107.

59. Thibaut Clément, Plus vrais que nature. Les parcs Disney, ou l'usage de la fiction de l'espace et le paysage (Paris: Presses de la Sorbonne Nouvelle, 2016).

60. Dallas W. Smythe, Counterclockwis e (Boulder, CO: Westview Press, 1994), 250-51. For structuralist, semiotic, or post-modern discussions of Disney parks' ideological subtext, see: Louis Marin, "Dégénérescence Utopique : Disneyland," in Utopiques : Jeux d'espace (Paris: Editions de Minuit, 1973), 297-324; Jean Baudrillard, Simulations (Los Angeles: Semiotext(e), Inc., 1983); Eco, Travels in Hyper Reality; Stephen M Fjellman, Vinyl Leaves: Walt Disney World And America (Boulder: Westview Press, 1992).

61. Upon the announcement of Universal Studios' arrival in Orlando, the Walt Disney Company rushed for the design and completion of its own Walt Disney's Hollywood Studios (originally Disney-MGM Studios), opening 13 months before its competitor on May 1, 1989. Universal's delay amounts to the time needed for it to go through the land-permitting process, from which Disney's Reedy Creek Improvement District was exempted. See: Foglesong, Married to the Mouse, 114.

62. Ellis W Hawley, "Herbert Hoover, the Commerce Secretariat, and the Vision of an 'Associative State,' 1921-1928," The Journal of American History 61, no. 1 (June 1974): 117.

\section{ABSTRACTS}

This paper sets out to examine ways in which the Disney company has come to enlist the help of private corporations in the design and operation of its theme parks, allowing the products and messages of large industrial conglomerates to take on increasing prominence the parks' environment. In their celebration of the free enterprise system, the parks have striven to not only create environments especially conducive to consumption but also extol private corporations as engines of progress. Disney's efforts to repackage industry help shed light on the media's role in a capitalist economy - namely, the promotion not just of individual companies but of a brand of capitalism most readily acceptable by the public.

\section{INDEX}

Keywords: Disney theme parks, participants, sponsors, political economy of the media, shopping centers, merchandising, consumerism

\section{AUTHOR}

\section{THIBAUT CLÉMENT}

Thibaut Clément is Associate Professor in American Studies at Sorbonne Université. His book Plus vrais que nature: les parcs Disney, ou l'usage de la fiction dans l'espace et le paysage was published by Les Presses de la Sorbonne Nouvelle in 2017. His research interests include the American landscape, socio-cognition, and the modes of consumption of mass culture. 